\title{
Exergy Analysis of a Turbo Expander: Modeling and Simulation
}

\author{
Adel El-Husseiny, ${ }^{1}$ Rania Farouq, ${ }^{2,}{ }^{*}$ Hassan A. Farag ${ }^{3}$ and Yehia El Taweel ${ }^{3}$ \\ ${ }^{1}$ Chemical Engineer, Assistant General Manager of Process, Projects Division, Abu Qir Petroleum Co., Elmoltaka Bldg. \\ TutankhAmoun St. Crossing To El ShahiedTayar Mahmoud Shaker Smouha - Sidi Gaber, Alexandria, Egypt. \\ ${ }_{2}^{2}$ Petrochemical Department, Faculty of Engineering, Pharos University, Canal El Mahmoudeya St. Semouha, \\ Alexandria, Egypt. \\ ${ }^{3}$ Chemical Engineering Department, Faculty of Engineering, Alexandria University, P. O. Box 21544; Alexandria, Egypt. \\ *Corresponding author: E-mail: rania.farouq@pua.edu.eg \\ Tel: (+203) 01002706756
}

Received: 04-17-2020

\begin{abstract}
Natural gas is a mixture that is widely used in the industries. Knowledge of its thermodynamic properties is essential for evaluating the process and equipment performance.

This paper quantifies the energy that can be extracted from natural gas using a turbo expander. Natural gases of wide-ranging compositions collected from 6 different gas fields in Egypt were investigated based on energy and exergy analysis. The study was conducted using MATLAB. Numerous simulation runs were made by taking various typical feed compositions classified as lean and rich.

The effects of increasing the amount of $\mathrm{C}_{1}, \mathrm{C}_{5}$ in the feed stream on the efficiency of energy utilization are presented. A validation analysis was performed. The results show similar trends and good agreements. It was concluded from the results that when the concentration of methane in the gas mixture increase, the exergetic efficiency decreases. The results also show that the values of thermodynamic properties depend on the relative amount of heavy components in the feed stream.
\end{abstract}

Keywords: Exergy efficiency, turbo-expander; peng Robinson; feed composition effect; natural gas

\section{Introduction}

Natural gas (NG) has become the primary source of energy in many countries. When it is extracted from refinery it has a high pressure of about $7 \mathrm{MPa}$ where it is consumed at the domestic and industrial sectors. In order to transport this high pressure gas to a distribution system where it is being consumed, its pressure should be reduced to a safe and usable level usually within 1.5-2 MPa. This is usually done in natural gas pressure reduction stations. Throttling valves are used to reduce the gas pressure where the physical exergy of high pressure gas is wasted. ${ }^{1-5}$ Energy recovery from natural gas distribution network is a strategy for sustainable energy in the urban area. ${ }^{6}$ For energy recovery purposes, the pressure drop can be exploited through dynamic or volumetric expanders by obtaining mechanical energy and thus electricity. ${ }^{7-8}$ There are several studies on recovering physical exergy of high pressure natural gas during pressure reduction pro- cess most of them focus on the pressure exergy recovering devices such as turboexpander. ${ }^{9-11}$

Researchers have developed case studies to estimate the amount of exergy recovery and the economics of turboexpander installations in NG pressure reduction stations. It was found that thermal efficiency of system increase about $8 \%$ in the optimum state ${ }^{12-14}$ some researchers developed a mathematical model to predict the performance of a twin-screw expander as power generation unit. ${ }^{15-16}$ Kuczynski et al presented formula that allows a quick and easy evaluation of the applicability of an expander on the selected gas regulation station. ${ }^{17} \mathrm{Ol}-$ fati et al. ${ }^{18}$ presented the energy and exergy analyses of a pressure reduction station. They investigated various operating conditions for station inlet pressure and temperature and the modification on preheating natural gas was considered. It was found that the energy consumption is reduced to $33 \%$ and the exergy destruction is reduced to 
$15 \%$. Osiadacz et al. investigate the factors influencing the efficiency of the gas expansion process application of turboexpanders at selected natural gas pressure regulator stations. ${ }^{9}$

The feed composition is an important factor that affects NGL recovery. The feed generally originates from upstream plants, so there may be a continuous variation in feed composition that causes plant instability. Feed composition has a seasonal variation, during cooler months the feed is a leaner gas and in the warmer months the feed is a richer gas. ${ }^{19-20}$

In this work, the effect of different feed characteristics on exergy efficiency was investigated; the process was simulated and analyzed to compare the differences in energy and thermodynamics properties (include exergy analysis). Different feed compositions were investigated and characterized under the basic classifications of lean and rich feed. A numerical method and a computer program were used to calculate the thermal properties of natural gas mixture such as enthalpy using Peng Robinson state equation. MATLAB has been utilized to model turbo-expander. The exergy analysis of a turbo-expander unit and the impact of various feed compositions has been investigated and validated according to the first and second laws of thermodynamics, and the performance of the TX is evaluated according to a different composition.

\section{Mathematical Model Development}

The NGL recovery for rich gas would require great power than lean gas, however; the more rich feed gas is, the more recovered condensate, the lower energy consumption per unit product consumed. ${ }^{19}$ Aspen HYSYS V10 software and Peng-Robinson equation of state are selected for process simulation. A model of the proposed unit has been created to determine the performance using real site data. Data for inlet pressure, temperature, flow rate, and required outlet pressure are key inputs.

The model will then calculate the rate of power and system efficiency. Numerical modeling of the exergy recovery is performed using MATLAB.

To study the different feed composition types; approximate composition and characteristics of the components of six typical feed natural gas samples were selected from six fields of six reservoirs shown in table 1 and the operating conditions are shown in table 2.

To simplify the proposed turbo-expander model, the following assumptions are made:

- There are no pressure losses in pipes and heat exchangers.

- The small difference between the intermediate pressure, the discharge pressure of the low-stage compressor and the suction pressure of the high-stage compressor is negligible. - The NG is dry; no gas hydrates are formed.

- The gearbox and generator efficiencies are considered to be constant.

Using the data in Tables 1 and 2, we made an algorithm for thermodynamic calculation of a turbo-expander in order to form correct input data for model calculations:

1. Gas pressure at turboexpander inlet: The main input was the inlet temperature, which was used for the calculation of the inlet pressure by using a Peng Robinson equation. The equation of Peng Robinson is an empirical equation of state that is derived from the Van der Waals equation, ${ }^{22-25}$ which is as follows:

$$
\mathrm{P}_{\mathrm{in}}=\frac{R * T_{\text {in }}}{V_{m}-b}-\frac{a}{V_{m}^{2}+2 * b * V_{m}-b^{2}}
$$

Where

$$
\begin{aligned}
& \mathrm{a}=\frac{\mathrm{R}^{2} * \mathrm{Tpc}^{2}}{2.1870 * \mathrm{Ppc}}\left(1+\mathrm{K}\left\{1-\mathrm{T}_{\mathrm{re}}{ }^{1 / 2}\right\}\right)^{2} \\
& \mathrm{~b}=\frac{\mathrm{R} * \mathrm{Tpc}}{12.8535 * \mathrm{Ppc}} \\
& \mathrm{K}=0.37464+1.54226 * \omega+0.26922 * \omega^{2}
\end{aligned}
$$

\begin{tabular}{|c|c|c|c|c|c|c|c|}
\hline \multicolumn{2}{|c|}{$\begin{array}{l}\text { Composition } \\
\text { (Mole \%) }\end{array}$} & $\begin{array}{c}1 \\
\text { Borapetco } \\
\text { El Salmiya-2 }\end{array}$ & $\begin{array}{c}2 \\
\text { PS } \\
\text { AES E2 } \\
\text { (TAMMAM) }\end{array}$ & $\begin{array}{c}3 \\
\text { PS } \\
\text { E6\#1/1 } \\
\text { AES- }\end{array}$ & $\begin{array}{c}4 \\
\text { Borapetco } \\
\text { ZZ-4X }\end{array}$ & $\begin{array}{c}5 \\
\text { AQP } \\
\text { W-A/Q A/Q } \\
\text { (Sep. Gas) }\end{array}$ & \multirow{2}{*}{$\begin{array}{c}6 \\
\text { AQP } \\
\text { (Feed Gas) } \\
0.0864\end{array}$} \\
\hline $\mathbf{N}_{2}$ & $\mathbf{N}_{2}$ & 0.95 & 0.905 & 0.617 & 0.059 & 0.1108 & \\
\hline $\mathrm{CO}_{2}$ & $\mathrm{CO}_{2}$ & 3.914 & 0.426 & 0.518 & 1.771 & 0.8264 & 0.6117 \\
\hline $\mathrm{H}_{2} \mathrm{~S}$ & $\mathbf{H}_{2} \mathbf{S}$ & 0 & 0 & 0 & 0 & 0 & 0 \\
\hline $\mathrm{C}_{1}$ & $\mathrm{C}_{1}$ & 63.807 & 78.915 & 79.888 & 80.53 & 88.857 & 93.375 \\
\hline $\mathrm{C}_{2}$ & $\mathrm{C}_{2}$ & 13.129 & 8.97 & 9.151 & 8.825 & 4.9658 & 3.2473 \\
\hline $\mathrm{C}_{3}$ & $\mathrm{C}_{3}$ & 8.656 & 5.483 & 4.898 & 4.135 & 2.3345 & 1.3393 \\
\hline $\begin{array}{l}\mathrm{iC}_{4} \\
\mathrm{nC}_{4}\end{array}$ & $\mathrm{C}_{4}$ & 4.808 & 3.045 & 2.854 & 1.919 & 1.2878 & 0.7635 \\
\hline $\begin{array}{l}\mathrm{iC}_{5} \\
\mathrm{nC}_{5}\end{array}$ & $\mathrm{C}_{5}$ & 1.924 & 1.308 & 1.318 & 1.026 & 0.3526 & 0.2715 \\
\hline $\mathrm{C}_{6+}$ & $\mathrm{C}_{6}+$ & 2.812 & 0.948 & 0.756 & 1.735 & 1.2655 & 0.3051 \\
\hline
\end{tabular}

Table 1. Typical feed selected to study 
Table 2. Feed operating conditions

\begin{tabular}{|c|c|c|c|c|c|c|}
\hline $\begin{array}{c}\text { Well \# } \\
\text { Company } \\
\text { Well Name }\end{array}$ & $\begin{array}{c}1 \\
\text { Borapetco } \\
\text { El Salmiya-2 }\end{array}$ & $\begin{array}{c}2 \\
\text { PS } \\
\text { AES E2 } \\
\text { (TAMMAM) }\end{array}$ & $\begin{array}{c}3 \\
\text { PS } \\
\text { AES-E6\#1/1 }\end{array}$ & $\begin{array}{c}4 \\
\text { Borapetco } \\
\mathrm{ZZ}-4 \mathrm{X}\end{array}$ & $\begin{array}{c}5 \\
\text { AQP } \\
\text { W-A/Q } \\
\text { (Sep. Gas) }\end{array}$ & $\begin{array}{c}\text { 6 } \\
\text { AQP } \\
\text { A/Q } \\
\text { (Feed Gas) }\end{array}$ \\
\hline $\begin{array}{c}\text { Production Rate } \\
\left(\mathrm{m}^{3} / \mathrm{hr}\right) \\
\text { Well Life in the Declining } \\
\text { Production Regime (Years) } \\
\text { Feed Pretreatment for } \\
\text { Transportation \& } \\
\text { its Conditions }\end{array}$ & $\begin{array}{c}17658 \\
13 \\
(2012-2025) \\
\text { Corrosion } \\
\text { Inhibitor } \\
\text { Injection }\end{array}$ & $\begin{array}{c}29429 \\
20 \\
(2009-2029) \\
\text { Corrosion } \\
\text { Inhibitor } \\
\text { Injection }\end{array}$ & $\begin{array}{c}23543 \\
15 \\
(2013-2033) \\
\text { Corrosion } \\
\text { Inhibitor } \\
\text { Injection }\end{array}$ & $\begin{array}{c}17658 \\
17 \\
(2012-2029) \\
\text { Corrosion } \\
\text { Inhibitor } \\
\text { Injection }\end{array}$ & $\begin{array}{c}58859 \\
25 \\
(2006-2031) \\
\text { Corrosion } \\
\text { Inhibitor } \\
\text { Injection }\end{array}$ & $\begin{array}{c}117717 \\
30 \\
(2000-2030) \\
\text { Corrosion } \\
\text { Inhibitor } \\
\text { Injection }\end{array}$ \\
\hline $\begin{array}{l}\text { The Design of a } \\
\text { Turbo-Expander \& its } \\
\text { Operating Modes } \\
\text { Max. F }\left(\mathrm{m}^{3} / \mathrm{hr}\right) \\
\text { Design } \mathrm{P}(\mathrm{KPa} g) \\
\text { Max. Design } \mathrm{T}\left({ }^{\circ} \mathrm{C}\right) \\
\text { Min Design } \mathrm{T}\left({ }^{\circ} \mathrm{C}\right) \\
\text { Operating Mode }\end{array}$ & $\begin{array}{c}58859 \\
7900 \\
80 \\
-35 \\
\text { Isentropic }\end{array}$ & $\begin{array}{c}88288 \\
6000 \\
80 \\
-20 \\
\text { Isentropic }\end{array}$ & $\begin{array}{c}88288 \\
6000 \\
80 \\
-20 \\
\text { Isentropic }\end{array}$ & $\begin{array}{c}58859 \\
7900 \\
80 \\
-35 \\
\text { Isentropic }\end{array}$ & $\begin{array}{c}141261 \\
11500 \\
58 \\
-70 \\
\text { Isentropic }\end{array}$ & $\begin{array}{c}141261 \\
11500 \\
58 \\
-70 \\
\text { Isentropic }\end{array}$ \\
\hline $\begin{array}{l}\text { Mechanical Efficiency } \\
\text { Electrical Efficiency }\end{array}$ & $\begin{array}{l}75 \% \\
70 \%\end{array}$ & $\begin{array}{l}80 \% \\
75 \%\end{array}$ & $\begin{array}{l}80 \% \\
75 \%\end{array}$ & $\begin{array}{l}75 \% \\
70 \%\end{array}$ & $\begin{array}{l}84 \% \\
80 \%\end{array}$ & $\begin{array}{l}84 \% \\
80 \%\end{array}$ \\
\hline $\begin{array}{c}\text { The Target Substances of } \\
\text { Petrochemical Synthesis \& } \\
\text { Engine Fuels Produced from } \\
\text { the HC's. }\end{array}$ & N.G (fuel) & N.G (fuel) & N.G (fuel) & LPG (fuel) & LPG (fuel) & LPG (fuel) \\
\hline
\end{tabular}

2. Determination of the thermodynamic fluid properties: the correlations of Farazneh-Gord \& Rahbari, ${ }^{26}$ were used. The correlations are based on measurable real-time properties such as Temperature, Pressure, and specific gravity (molecular weight) of the natural gas for the non-measurable thermodynamic properties such as Entropy, Enthalpy, and Internal energy. 3.

$$
\begin{aligned}
& \mathrm{h}_{\mathrm{i}}\left(\mathrm{T}^{\prime}, \mathrm{P}^{\prime}, \Upsilon^{\prime}\right)=\mathrm{A}_{1}\left(\mathrm{~T}^{\prime}, Y^{\prime}\right) \mathrm{P}^{\prime 4}+\mathrm{A}_{2}\left(\mathrm{~T}^{\prime}, Y^{\prime}\right) \mathrm{P}^{\prime 3}+ \\
& +\mathrm{A}_{3}\left(\mathrm{~T}^{\prime}, \Upsilon^{\prime}\right) \mathrm{P}^{\prime 2}+ \\
& \mathrm{A}_{4}\left(\mathrm{~T}^{\prime}, \Upsilon^{\prime}\right) \mathrm{P}^{\prime}+\mathrm{A}_{5}\left(\mathrm{~T}^{\prime}, \Upsilon^{\prime}\right)
\end{aligned}
$$

Where

$A_{i}\left(T^{\prime}, \Upsilon^{\prime}\right) ; I=1, \ldots, 5$ are defined as:

$\mathrm{A}_{\mathrm{i}}\left(\mathrm{T}^{\prime}, \Upsilon^{\prime}\right)=\mathrm{B}_{1}\left(\mathrm{~T}^{\prime}\right)^{\prime} \Upsilon^{\prime 2}+\mathrm{B}_{2}\left(\mathrm{~T}^{\prime}\right)^{\prime} \Upsilon^{\prime}+\mathrm{B}_{3}\left(\mathrm{~T}^{\prime}\right)$

And $B_{j}(T) ; j=1,2,3$ for each $A_{i}\left(T^{\prime},{ }^{\prime} Y^{\prime}\right)$ are defined as: $\mathrm{B}_{\mathrm{j}}\left(\mathrm{T}^{\prime}\right)=\mathrm{C}_{1} \mathrm{~T}^{\prime 2}-\mathrm{C}_{2} \mathrm{~T}^{\prime}-\mathrm{C}_{3}$

Where: T, $\mathrm{P}$, and ' $\mathrm{Y}$ ' are functions of $\mathrm{T}, \mathrm{P}$, and gas specific gravity respectively as follows:

$$
\begin{aligned}
& \mathrm{T}_{\mathrm{i}}{ }^{\prime}=\frac{\mathrm{T}_{\text {in }}-300}{50}, \quad \mathrm{P}_{\mathrm{i}}{ }^{\prime}=\frac{\mathrm{P}_{\text {in }}-13}{7.3598}, \quad \Upsilon_{\mathrm{i}}=\frac{\mathrm{M}_{\mathrm{wt}}}{28.966}, \\
& \Upsilon_{\mathrm{i}}{ }^{\prime}=\frac{\Upsilon_{\mathrm{i}}-0.62541}{0.07894}
\end{aligned}
$$

3. Exergy analysis: Exergy analysis is based on the first and second laws of thermodynamics and is employed to calculate the maximum useful power accessible by an assigned amount of input energy to a process. By neglecting the effects of kinetic, potential and nuclear energies (unchanged or insignificant), the total exergy can be divided into two parts, chemical, and physical exergy. Eqs. (3) - (5) express the exergy destruction, the total exergy, and the physical exergy, respectively

$$
\begin{aligned}
& \mathrm{E}^{\cdot}{ }_{\text {destroyed }}=\mathrm{T}_{\mathrm{o}} \mathrm{S}^{\cdot} \\
& \mathrm{E}^{\cdot}=\mathrm{E}^{\cdot \mathrm{ph}^{\mathrm{ph}}}+\mathrm{E}^{\cdot \text { chem }} \\
& \mathrm{E}^{\cdot \mathrm{ph}^{\prime}}=\left(\mathrm{H}^{\cdot}-\mathrm{H}_{\mathrm{o}}{ }_{\mathrm{o}}\right)-\mathrm{T}_{\mathrm{o}}\left(\mathrm{S}^{\cdot}-\mathrm{S}_{\mathrm{o}}{ }_{\mathrm{o}}\right)
\end{aligned}
$$

4. Calculation of the turbo-expander efficiency: The outlet enthalpy is used in conjunction with the isentropic enthalpy and inlet enthalpy to determine isentropic expansion efficiency. The working fluid enters the turbo-expander and expands to the discharge pressure with the turbo-expander efficiency is defined as:

$$
\eta_{\mathrm{E}}=\frac{\mathrm{h}_{\mathrm{i}}-h_{o}}{\mathrm{~h}_{\mathrm{i}}-\mathrm{h}_{o, s, e}}
$$

5. The electrical power obtained from the exergy recovery process can be expressed as:

$$
W \cdot{ }_{\mathrm{Gen}}=m \cdot{ }_{\mathrm{N} \cdot \mathrm{G}}\left(\mathrm{h}_{\mathrm{i}}-\mathrm{h}_{\mathrm{o}}\right) \cdot \eta_{\mathrm{GB}} \cdot \eta_{\mathrm{Ge}}
$$


6. The exergetic efficiency of the recovery can be obtained by comparing the reversible expansion work to the actual work produced by the electric generator. Therefore, by substituting in the following form:

$$
\eta_{I I, P}=\frac{w_{G e n}^{\prime}}{w_{R e v}^{\prime}}=\frac{\left(\mathrm{h}_{\mathrm{i}}-\mathrm{h}_{\mathrm{o}}\right) \cdot \eta_{\mathrm{GB}} \cdot \eta_{\mathrm{Gen}}}{\left\{\mathrm{h}_{\mathrm{i}}-\mathrm{h}_{\mathrm{o}, \mathrm{s}, \mathrm{e}}-\mathrm{T}_{\mathrm{o}}\left(\mathrm{S}_{\mathrm{i}}-\mathrm{S}_{\mathrm{o}, \mathrm{s}, \mathrm{e}}\right)\right\}}
$$

\section{Results and Discussion}

Because of the natural gas composition variation in the selected samples is the one who plays the main role in the study, and also methane content represents the huge fraction of that composition. ${ }^{19}$ Therefore, the impact of the methane concentration variation on the selected samples of the thermodynamic properties was studied and validated using Aspen HYSYS V10. By entering the different feed compositions and operating condition; the HYSYS program calculates the thermodynamic properties of the different streams shown in table $3 \& 4$ from which expander and exergetic efficiency can be predicted.

\section{1. Studying Gas Composition Variation Effect on Enthalpy}

In this case, the selected feed samples are arranged in increasing order of hydrocarbon contents, from the $\mathrm{C}_{1}$ content to heavier hydrocarbon.
Also, pentane content and its variations in the natural gas composition have been chosen as a basis to show its effect as a heavy component on the previous mentioned thermodynamic properties. In this case, the selected feed samples are re-arranged in decreasing order of hydrocarbon contents, from $\mathrm{C}_{5}$ content to lighter hydrocarbon.

The first four feed samples (1-4) are classified as rich feed, while the remaining two feed samples (5\&6) are taken as lean feed.

The classification for rich feed is merely based on the contents of $\mathrm{C}_{2}$ and/or $\mathrm{C}_{3}$. If the $\mathrm{C}_{2}$ content is less than $8 \%$ or the $\mathrm{C}_{3}$ content less than $3 \%$ or the $\mathrm{C}_{2}$ plus $\mathrm{C}_{3}$ contents less than $10 \%$, the feed is considered a lean feed; otherwise, it is taken as a rich feed. ${ }^{24}$

\section{1. 1. Effect of Methane Concentration Variation on Inlet, Outlet and Isentropic Outlet Enthalpy}

To sense their effects on each other, the inlet conditions (pressure and temperature) for all gas samples were kept the same as typical actual plant conditions at 6620 $\mathrm{KPa}$ and $21.9^{\circ} \mathrm{C}$ respectively.

As shown from table 3; the difference in the feed enthalpy for the six feed types arises from the variation of the feed compositions. The relationship between the variation in methane concentration and the enthalpy of the gas mixture is a close linear relationship in an inverse proportion

Table 3. Effect of Methane concentration (C1\%) variation on all properties

\begin{tabular}{|c|c|c|c|c|c|c|c|}
\hline $\mathrm{C}_{1}$ (mol. \%) & $\begin{array}{l}\text { Well \# } \\
\text { Units }\end{array}$ & $\begin{array}{c}1^{\text {st }} \\
63.807\end{array}$ & $\begin{array}{c}2^{\text {nd }} \\
78.915\end{array}$ & $\begin{array}{c}3^{\text {rd }} \\
79.888\end{array}$ & $\begin{array}{c}4^{\text {th }} \\
80.53\end{array}$ & $\begin{array}{c}5^{\text {th }} \\
88.8566\end{array}$ & $\begin{array}{c}6^{\text {th }} \\
93.3752\end{array}$ \\
\hline \multicolumn{8}{|l|}{ Property } \\
\hline $\mathbf{h}_{\text {in }}$ & $(\mathrm{kJ} / \mathrm{kg})$ & -37.144 & -40.083 & -40.269 & -40.318 & -41.669 & -42.470 \\
\hline $\mathbf{h}_{\text {out }}$ & $(k J / k g)$ & -82.018 & -83.302 & -83.503 & -90.300 & -96.931 & -97.746 \\
\hline $\mathbf{T}_{\text {out }}$ & $\left({ }^{\circ} \mathrm{C}\right)$ & -17.560 & -17.770 & -17.880 & -22.410 & -26.280 & -26.480 \\
\hline $\mathbf{h}_{\text {out }, e, s}$ & $(\mathrm{~kJ} / \mathrm{kg})$ & -52.20 & -55.64 & -55.95 & -55.86 & -57.13 & -57.80 \\
\hline $\mathrm{T}_{\text {out }, e, s}$ & $\left({ }^{\circ} \mathrm{C}\right)$ & 2.57 & 0.78 & 0.59 & 0.66 & 0.23 & 0.03 \\
\hline $\mathbf{S}_{i n}$ & $(k J / k g . k)$ & -1.504 & -1.539 & -1.541 & -1.542 & -1.557 & -1.565 \\
\hline $\mathrm{S}_{\text {out }, e, s}$ & $(k J / k g . k)$ & -1.388 & -1.411 & -1.413 & -1.413 & -1.426 & -1.433 \\
\hline
\end{tabular}

Table 4. Effect of Pentane concentration $\left(\mathrm{C}_{5} \%\right)$ variation on all properties

\begin{tabular}{|c|c|c|c|c|c|c|c|}
\hline $\mathrm{C}_{5}$ (mol. \%) & $\begin{array}{l}\text { Well \# } \\
\text { Units }\end{array}$ & $\begin{array}{c}1^{\text {st }} \\
1.924\end{array}$ & $\begin{array}{c}2^{\text {nd }} \\
1.318\end{array}$ & $\begin{array}{c}3^{\text {rd }} \\
1.308\end{array}$ & $\begin{array}{c}4^{\text {th }} \\
1.026\end{array}$ & $\begin{array}{c}5^{\text {th }} \\
0.3526\end{array}$ & $\begin{array}{c}6^{\text {th }} \\
0.2715\end{array}$ \\
\hline \multicolumn{8}{|l|}{ Property } \\
\hline $\mathbf{h}_{\text {in }}$ & $(\mathrm{kJ} / \mathrm{kg})$ & -37.144 & -40.318 & -40.082 & -40.269 & -41.669 & -42.469 \\
\hline $\mathbf{h}_{\text {out }}$ & $(\mathrm{kJ} / \mathrm{kg})$ & -82.018 & -83.503 & -83.302 & -90.300 & -96.931 & -97.746 \\
\hline $\mathrm{T}_{\text {out }}$ & $\left({ }^{\circ} \mathrm{C}\right)$ & -17.560 & -17.880 & -17.770 & -22.410 & -26.280 & -26.480 \\
\hline $\mathbf{h}_{\text {out }, e, s}$ & $(\mathrm{~kJ} / \mathrm{kg})$ & -52.20 & -55.95 & -55.64 & -55.86 & -57.13 & -57.80 \\
\hline $\mathrm{T}_{\text {out }, e, s}$ & $\left({ }^{\circ} \mathrm{C}\right)$ & 2.57 & 0.59 & 0.78 & 0.66 & 0.23 & 0.03 \\
\hline $\mathrm{S}_{\text {in }}$ & $(k J / k g . k)$ & -1.504 & -1.541 & -1.539 & -1.542 & -1.557 & -1.565 \\
\hline $\mathrm{S}_{\text {out }, e, s}$ & $(k J / k g . k)$ & -1.433 & -1.426 & -1.413 & -1.411 & -1.413 & -1.388 \\
\hline
\end{tabular}


which means that by increasing methane concentration; the inlet and outlet enthalpy decreases while decreasing pentane concentration decreases the enthalpy. It is observed that the leaner feed generally give lower duty than those of rich feed. This is due to the presence of high heavier hydrocarbons $\left(\mathrm{C}_{5}^{+}\right)$components in the rich feed.

a) Effect of methane concentration variation on outlet enthalpy:Using Constant Operating Conditions

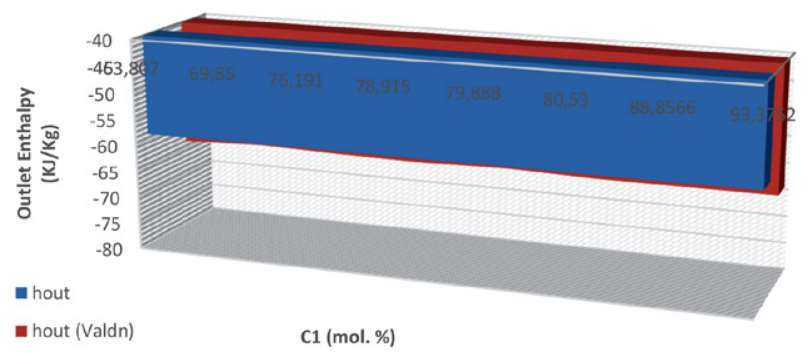

Fig. 1. Effect of methane concentration variation on outlet enthalpy $(\mathrm{kJ} / \mathrm{kg})$, Constant outlet conditions

Figure (1) shows the relation between the variation in methane concentration (mole \%) and the outlet enthalpy $(\mathrm{kJ} / \mathrm{kg})$ in case of unification of the outlet conditions (pressure and temperature) at $2600 \mathrm{KPa}$ g and $-2.2{ }^{\circ} \mathrm{C}$ as follows:

The methane rejection (The ratio of the molar flow of methane "residue" to the molar flow of methane "natural-gas feed") is directly related to the feed-stream temperature on which the product temperature depends on. Rejection increases with decreasing temperature; however, in Konukman et.al (2005), ${ }^{27}$ the methane rejection was found to be not very sensitive to the feed-stream temperature and in turn to the product temperature, and because outlet enthalpy depends on the temperature at a given pressure. So it is concluded that increasing methane $\%$ will not affect outlet enthalpy.

\section{b) Using Variable Operating Conditions}

To study the effect of changing the operating conditions on the variation in the outlet enthalpy, the plant real

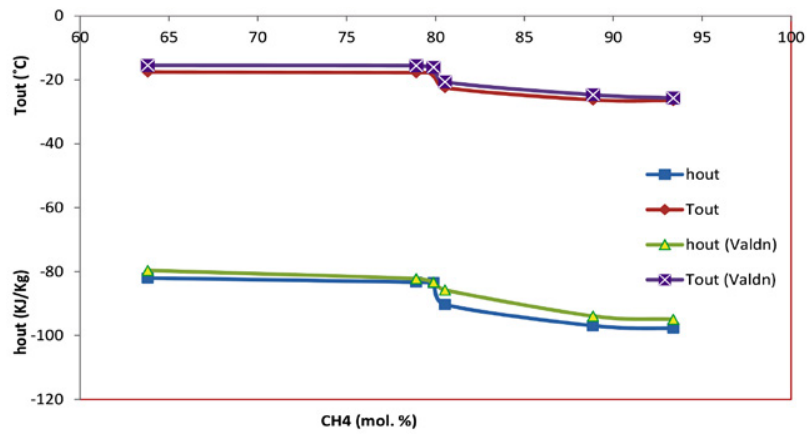

Fig. 2. Effect of methane concentration variation on outlet enthalpy $(\mathrm{kJ} / \mathrm{kg})$ and outlet temperature $\left({ }^{\circ} \mathrm{C}\right)$, Variable outlet conditions data were used for that by taking the required turbine duty to expand a certain gas sample from the utilized typical feed samples in this work, which corresponds to approximately $4000 \mathrm{KPa}$ pressure drops and taking this value as a reference and set for all other samples.

Consequently, it has resulted in a change in outlet conditions (pressure and temperature). Therefore, the changes in the outlet enthalpy for all samples were obtained and recorded in figure (2).

The relatively high linearity deviation is almost due to some erratic points. Mainly these points of the rich samples, and for this reason, the enthalpy is raised.

\section{1. 2. Effect of Pentane Concentration Variation on Inlet; Outlet; Isentropic Outlet Enthalpy}

Table 4 shows the relationship between the variation in pentane concentration, and the inlet enthalpy of the gas mixture is a non-linear direct proportional relationship. It is observed that the leaner feed generally give lower duty than those of rich feed. This is due to the presence of high heavier hydrocarbons $\left(\mathrm{C}_{5}^{+}\right)$components in the rich feed.

\section{2. Effect of Feed Composition on Entropy}

\section{2. 1. Effect of Methane Concentration Variation on Inlet and Outlet Entropy}

Table 3 shows the relationship between the variation in methane concentration, and the inlet entropy of the gas mixture is a closely linear relationship in an inverse proportion. The results are consistent with the one observed in the discussion of the relation between methane concentration and the inlet enthalpy. As known, the value of enthalpy is proportional to the values of entropy.

\section{2. 2. Effect of Pentane Concentration Variation on the Inlet and Outlet Entropy}

From the illustrated table 4 , the relationship between the variation in pentane concentration, and the inlet entropy of the gas mixture is nearly a non-linear direct proportional relationship. As mentioned before, it can be concluded that the leaner feed generally give lower entropy content than those of rich feed. This is also like enthalpy due to the presence of high heavier hydrocarbons $\left(\mathrm{C}_{5}{ }^{+}\right)$ components in the rich feed.

\section{3. Effect of Feed Composition on Expander Efficiency}

\section{3. 1. Effect of Methane Concentration Variation on Expander Efficiency}

As shown in the figure (3); the relationship between the variation in methane concentration and the expander efficiency of the gas mixture is a close linear in an inverse 

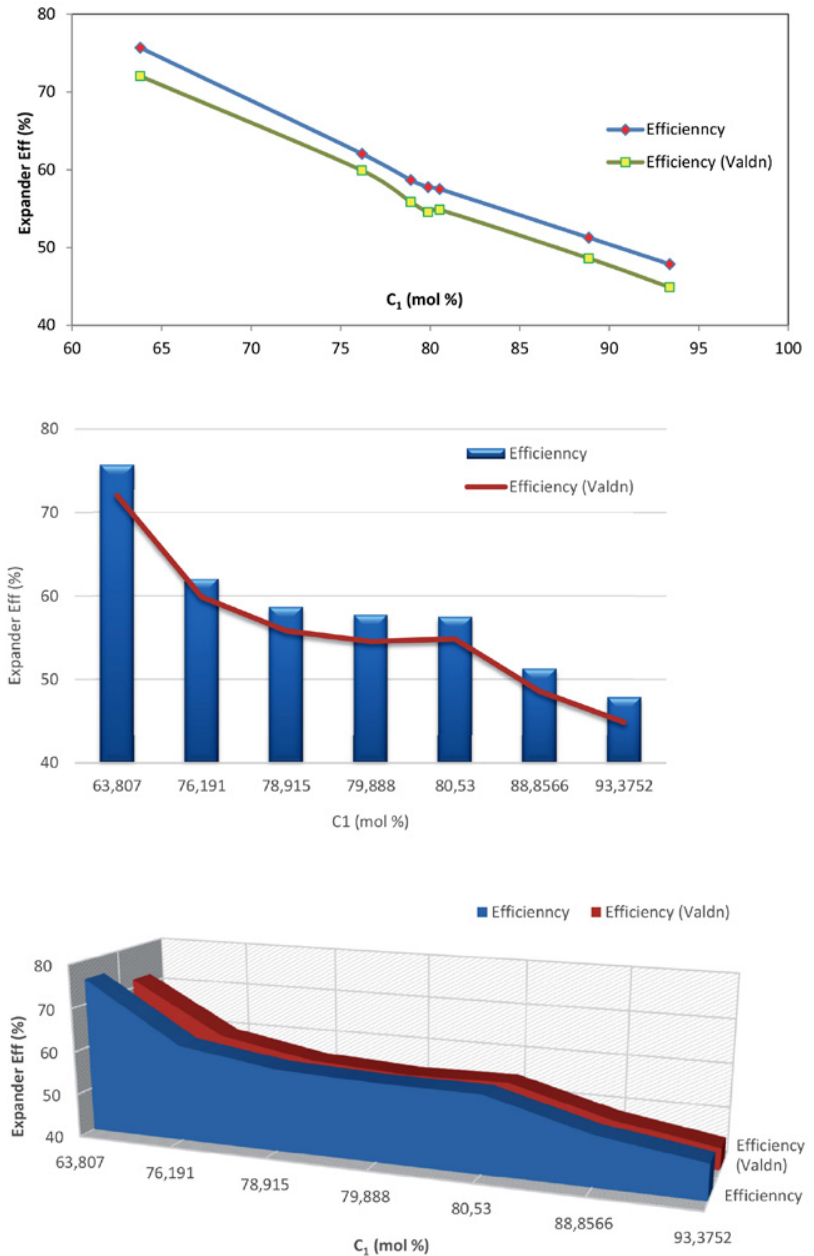

Fig. 3. Effect of methane concentration variation on expander Efficiency $(\%)$

proportion. i.e., when the concentration of methane in the gas mixture increases, the expander efficiency decreases.

Since at standard condition the heat capacity at constant pressure (Cp) of methane is higher than other hydrocarbons present in the natural gas mixture, $\mathrm{Cp}$ of the mixture will be increased in a higher concentration of methane. When $\mathrm{Cp}$ of the fluid increases, the required compression work to reach a certain pressure will be decreased. Also, by increasing the concentration of methane in the mixture the molecular weight and the specific heat ratio $(\mathrm{k}=\mathrm{Cp} /$ $\mathrm{Cv}$ ) of the fluid will be decreased.

\section{3. 2. Effect of Pentane Concentration Variation on Expander Efficiency}

From the illustrated figure (4); the relationship between the variation in pentane concentration and expander efficiency of the gas mixture is a quasi-linear direct proportional relationship.

It is observed also the leaner feed generally give higher efficiency than those of rich feed. This is due to the
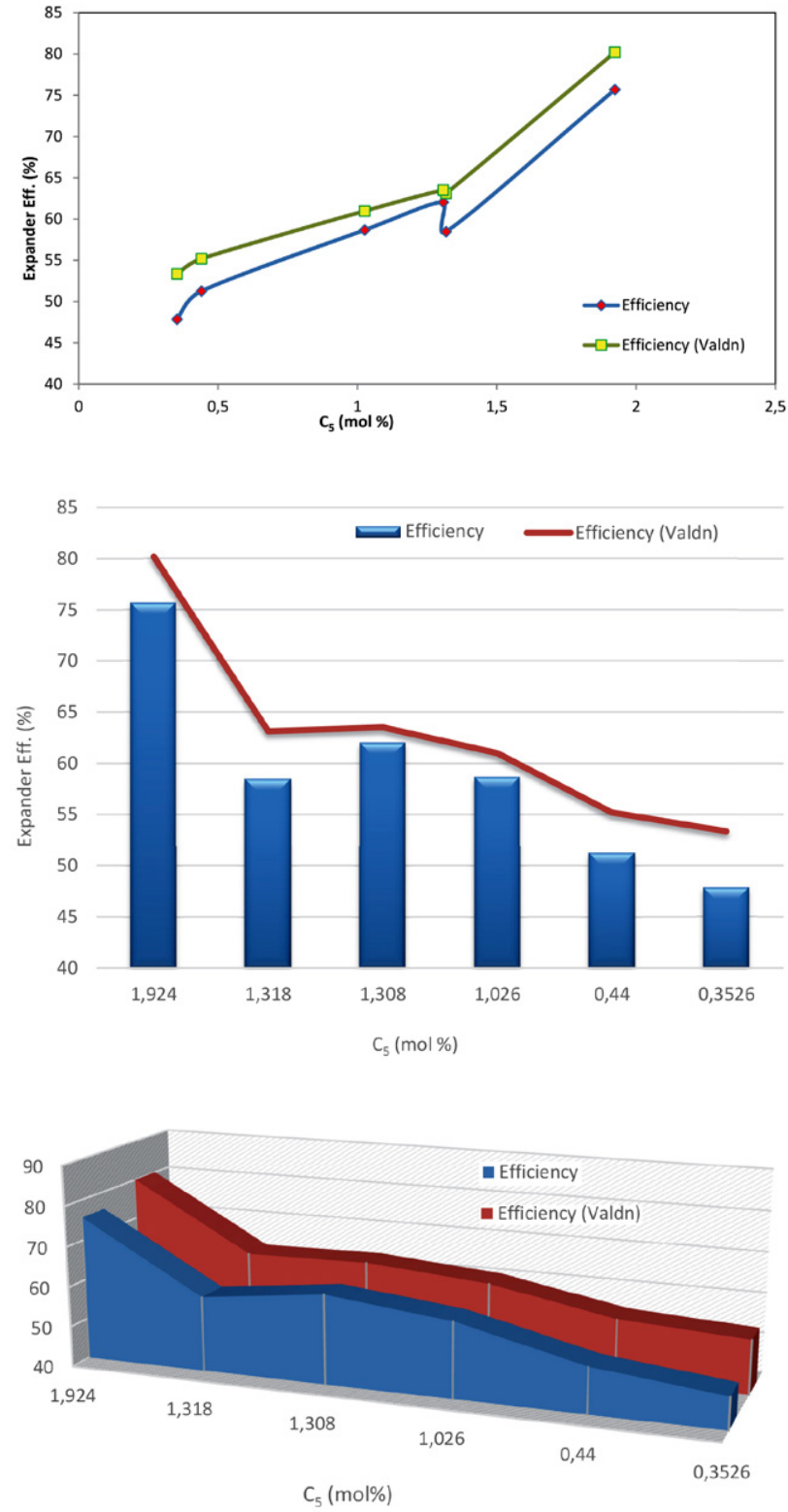

Fig. 4. Effect of Pentane Concentration Variation on Expander Efficiency $(\%)$

presence of high heavier hydrocarbons $\left(\mathrm{C}_{5}{ }^{+}\right)$components in the rich feed.

\section{4. Effect of Feed Composition on Exergetic Efficiency}

\section{4. 1. Effect of Methane Concentration Variation on Exergetic Efficiency}

As shown in the figure (5); the relationship between the variation in methane concentration and the exergetic efficiency of the gas mixture is a close linear in an inverse proportion. i.e., when the concentration of methane in the gas mixture increases, the exergetic efficiency decreases. 

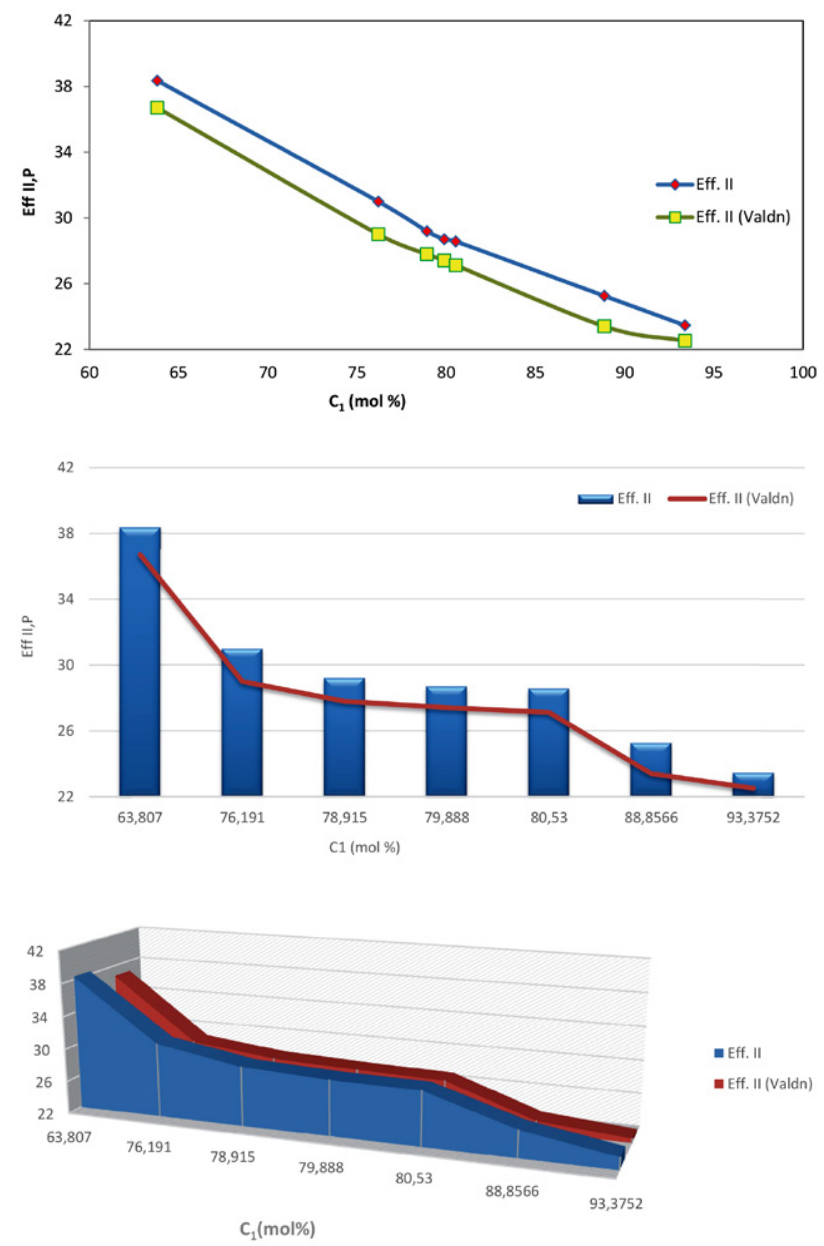

Fig. 5. Effect of methane concentration variation on exergetic Efficiency $(\%)$

\section{4. 2. Effect of Pentane Concentration Variation on Exergetic Efficiency}

From the illustrated figure (6); the relationship between the variation in pentane concentration and the exergetic efficiency of the gas mixture is a quasi-linear direct proportional relationship. It is observed also the leaner feed generally give lower exergetic efficiency than those of rich feed. This is due to the presence of high heavier hydrocarbons $\left(\mathrm{C}_{5}{ }^{+}\right)$components in the rich feed.

The linearity deviation is attributed to inaccurate points. Mainly such points are of the rich samples, and for this reason, the exergetic efficiency is raised.

\section{Conclusions}

Fifteen typical feed samples from ten gas reservoirs were obtained from four petroleum companies located at places that are spaced from each other between the Eastern \& Western deserts of Egypt. Just six feeds from six gas reservoirs that have significant concentration differences were chosen as a study-base.
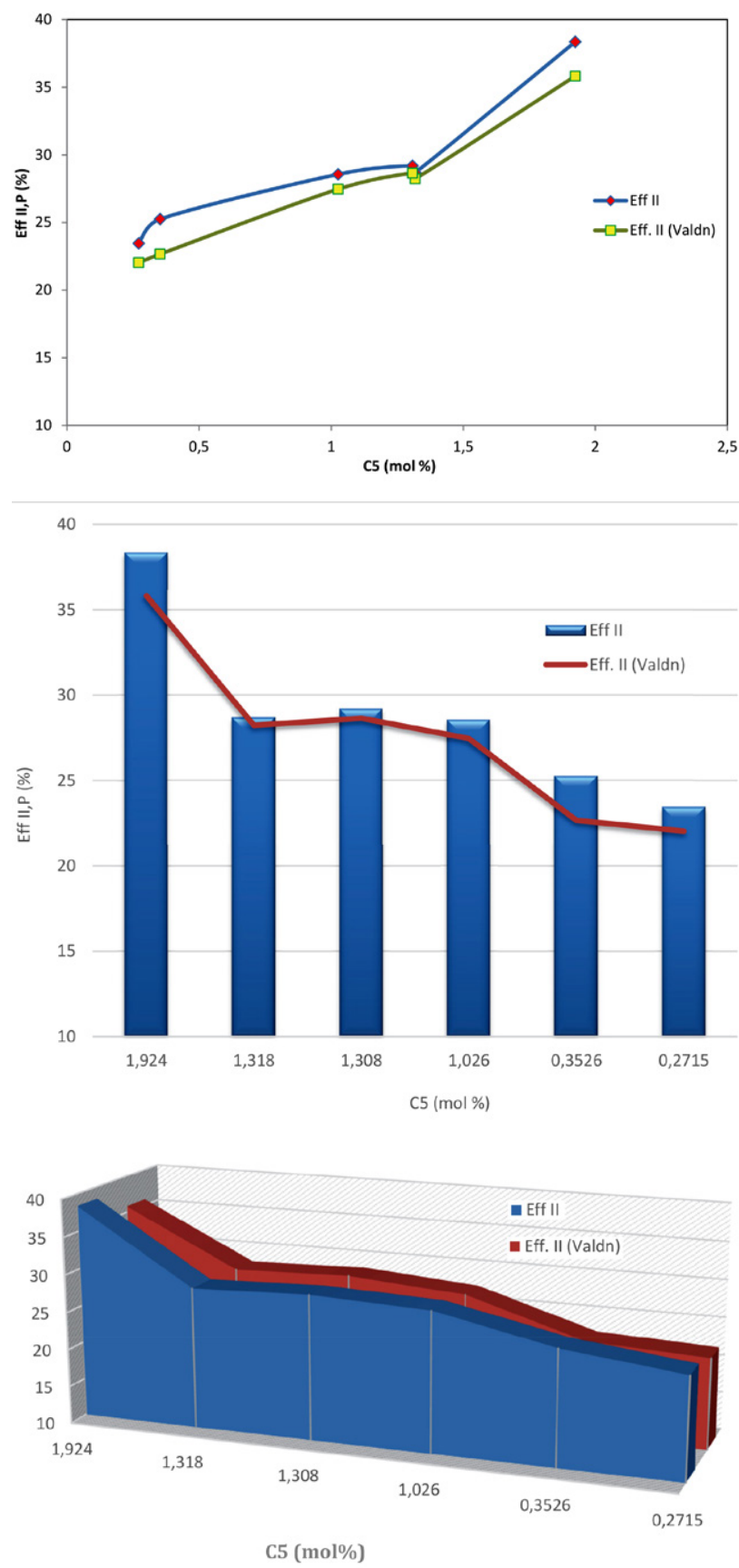

Fig. 6. Effect of Pentane Concentration Variation on Exergetic Efficiency $(\%)$

Math models were developed based on Peng-Robinson correlation to predict the performance data of a turbo-expander handling N.G. The models were solved by MATLAB software, validated and analyzed to get the most asymptotic model of reality to be further developed.

The obtained data are near those obtained by other researchers; ${ }^{28}$ which mean that the model was successful in predicting the thermodynamic properties of different gas composition such as inlet \& outlet enthalpies, inlet \& outlet entropies, expander \& exergetic efficiencies and isentropic outlet enthalpy. Validation was performed for 
verification of the results and shows good agreement with the calculated properties.

\section{Nomenclature}

\begin{tabular}{|c|c|c|}
\hline a & & $\begin{array}{l}\text { Measure of the Strength of Attraction } \\
\text { between the Gas Molecules }\end{array}$ \\
\hline $\mathrm{b}$ & : & $\begin{array}{l}\text { Volume Occupied by gas molecules, which } \\
\text { decreases the available open volume }\end{array}$ \\
\hline $\mathrm{H}$ & : & Enthalpy, $\mathrm{kJ} / \mathrm{kg}$ \\
\hline $\mathrm{h}_{\mathrm{i}}$ & • & Inlet Enthalpy, $\mathrm{kJ} / \mathrm{kg}$ \\
\hline $\mathrm{h}_{\mathrm{o}}$ & . & Outlet Enthalpy, $\mathrm{kJ} / \mathrm{kg}$ \\
\hline$h_{o, s, e}$ & • & Isentropic Outlet Enthalpy, $\mathrm{kJ} / \mathrm{kg}$ \\
\hline $\mathrm{m}$ N.G & ${ }^{\circ}$ & Natural Gas Mass Flow Rate \\
\hline $\mathrm{P}$ & : & Pressure, $K P a g$ \\
\hline Pc & $\cdot$ & Critical Pressure, $\mathrm{KPa} g$ \\
\hline Pi' & • & Dimensionless Index in Novel Correlation \\
\hline Ppc & - & $\begin{array}{l}\text { Pseudo Critical Pressure for the mixture, } \\
K P a g\end{array}$ \\
\hline $\operatorname{Pr}$ & : & Reduced Pressure, dimensionless \\
\hline $\mathrm{P}_{V P}$ & : & $\begin{array}{l}\text { Saturated Vapor Pressure of the gas at a } \\
\text { temperature } \mathrm{T}=0.7 \mathrm{Tc}\end{array}$ \\
\hline Q & : & Inlet Volumetric Flowrate, $m^{3} / h r$. \\
\hline $\mathrm{R}$ & & Universal Gas Constant, $\left(\mathrm{Pa} \cdot \mathrm{m}^{3} / \mathrm{mol} \cdot \mathrm{k}\right)$ \\
\hline $\mathrm{S}_{\mathrm{i}}$ & & Inlet Entropy, $\mathrm{kJ} / \mathrm{kg} \cdot \mathrm{K}$ \\
\hline $\mathrm{S}_{\mathrm{o}, \mathrm{s}, \mathrm{e}}$ & & Isentropic Outlet Entropy, $\mathrm{kJ} / \mathrm{kg} \cdot \mathrm{K}$ \\
\hline $\mathrm{T}$ & . & Temperature, $K$ \\
\hline Tc & : & Critical Temperature, $K$ \\
\hline Ti' & : & Dimensionless Index in Novel Correlation \\
\hline $\mathrm{Tp}_{\mathrm{c}}$ & : & $\begin{array}{l}\text { Pseudo Critical Temperature for the } \\
\text { mixture, } K\end{array}$ \\
\hline $\operatorname{Tr}$ & : & Reduced Temperature, dimensionless \\
\hline $\mathrm{V}$ & - & Gas Volume, $m^{3}$ \\
\hline $\mathrm{V}_{\mathrm{m}}$ & : & Molar Volume, $\mathrm{m}^{3} / \mathrm{mol}$ \\
\hline $\mathrm{W} \cdot \mathrm{Gen}$ & : & $\begin{array}{l}\text { Electrical Power Obtained from the Exergy } \\
\text { Recovery Process }\end{array}$ \\
\hline$W^{\prime}{ }_{\operatorname{Rev}}$ & e & Reversible Expansion Work \\
\hline Yi & : & Dimensionless Index in Novel Correlation \\
\hline $\begin{array}{c}Y i \\
\omega\end{array}$ & : & $\begin{array}{l}\text { Dimensionless Index in Novel Correlation } \\
\text { acentric factor }\end{array}$ \\
\hline
\end{tabular}

\section{Reference}

1. Farzaneh-Gord, M., Ghezelbash, R., Sadi, M., \& Moghadam, A. J. (2016). Integration of vertical ground-coupled heat pump into a conventional natural gas pressure drop station: Energy, economic and CO2 emission assessment. Energy, 112, 998-1014. DOI:10.1016/j.energy.2016.06.100

2. Jannatabadi, M., Farzaneh-Gord, M., Rahbari, H. R., \& Nersi, A. (2018). Energy and exergy analysis of reciprocating natural gas expansion engine based on valve configurations. Energy, 158, 986-1000. DOI:10.1016/j.energy.2018.06.103

3. Naderi, M., Ahmadi, G., Zarringhalam, M., Akbari, O., \& Khalili, E. (2018). Application of water reheating system for waste heat recovery in NG pressure reduction stations, with experimental verification. Energy, 162, 1183-1192.

DOI:10.1016/j.energy.2018.08.111

4. Neseli, Mehmet Alparslan, Onder Ozgener, and Leyla Ozgener. "Energy and exergy analysis of electricity generation from natural gas pressure reducing stations." Energy Conversion and Management 2015, 93, 109-120.

DOI:10.1016/j.enconman.2015.01.011

5. Olfati, Mohammad, Mehdi Bahiraei, Setareh Heidari, and Farzad Veysi. "A comprehensive analysis of energy and exergy characteristics for a natural gas city gate station considering seasonal variations." Energy 2018, 155, 721-733.

DOI:10.1016/j.energy.2018.05.069

6. Golchoobian, H., Taheri, M. H., \& Saedodin, S. (2019). Thermodynamic analysis of turboexpander and gas turbine hybrid system for gas pressure reduction station of a power plant. Case Studies in Thermal Engineering, 14, 100488.

DOI:10.1016/j.csite.2019.100488

7. Farzaneh-Gord, M., Izadi, S., Pishbin, S. I., Sheikhani, H., \& Deymi-Dashtebayaz, M. (2015). Thermodynamic analysis of medium pressure reciprocating natural gas expansion engines. Polish Journal of Chemical Technology, 17(2), 119125. DOI:10.1515/pjct-2015-0039

8. Barone, G., Buonomano, A., Calise, F., \& Palombo, A. (2018). Natural gas turbo-expander systems: A dynamic simulation model for energy and economic analyses. Thermal Science, 22(5), 2215-2233. DOI:10.2298/TSCI180109276B

9. Osiadacz, A., Chaczykowski, M., \& Kwestarz, M. (2017). An evaluation of the possibilities of using turboexpanders at pressure regulator stations. Journal of Power Technologies, 97(4), 289-294.

10. Sheikhnejad, Y., Simões, J., \& Martins, N. (2020). Energy Harvesting by a Novel Substitution for Expansion Valves: Special Focus on City Gate Stations of High-Pressure Natural Gas Pipelines. Energies, 13(4), 956. DOI:10.3390/en13040956

11. Morgese, G., Fornarelli, F., Oresta, P., Capurso, T., Stefanizzi, M., Camporeale, S. M., \& Torresi, M. (2020). Fast Design Procedure for Turboexpanders in Pressure Energy Recovery Applications. Energies, 13(14), 3669.

DOI:10.3390/en13143669

12. Saadat-Targhi, M., \& Khanmohammadi, S. (2019). Energy and exergy analysis and multi-criteria optimization of an integrated city gate station with organic Rankine flash cycle and thermoelectric generator. Applied Thermal Engineering, 149, 312-324. DOI:10.1016/j.applthermaleng.2018.12.079

13. Ahmadi, G., Toghraie, D., \& Akbari, O. (2019). Energy, exergy and environmental (3E) analysis of the existing CHP system in a petrochemical plant. Renewable and Sustainable Energy Reviews, 99, 234-242.

DOI:10.1016/j.rser.2018.10.009

14. Islam, S.U.; Ahmed, I.; Din, Z.U. Energy Recovery Opportunity at Natural Gas Regulating Station byreplacing Pressure Control Valve with Turbo Expander using Aspen HYSYS: A case study of WAH SMS(Sale Metering Station ).Int. J. Innov. Sci. Eng. Technol.2016,3, 464-475

15. Yao, S.; Zhang, Y.; Deng, N.; Yub, X.; Dong, S. Performance Research on a Power Generation System Using Twin-Screw 
Expanders for Energy Recovery at Natural Gas Pressure Reduction Stations under Off-Design Conditions. Appl. Energy 2019, 236, 1218-1230.

DOI:10.1016/j.apenergy.2018.12.039

16. Tian, Y.; Xing, Z.; He, Z.; Wu, H. Modeling and Performance Analysis of Twin-Screw Steam Expander under Fluctuating Operating Conditions in Steam Pipeline Pressure Energy Recovery Applications. Energy 2017, 141, 692-701.

DOI:10.1016/j.apenergy.2018.12.039

17. Kuczyński, S., Łaciak, M., Olijnyk, A., Szurlej, A., \& Włodek, T. (2019). Techno-economic assessment of turboexpander application at natural gas regulation stations. Energies, 12(4), 755. DOI:10.3390/en12040755

18. Olfati, M., Bahiraei, M., \& Veysi, F. (2019). A novel modification on preheating process of natural gas in pressure reduction stations to improve energy consumption, exergy destruction and $\mathrm{CO} 2$ emission: Preheating based on real demand. Energy, 173, 598-609.

DOI:10.1016/j.energy.2019.02.090

19. Jiang, H., Zhang, S., Jing, J., \& Zhu, C. (2019). Thermodynamic and economic analysis of ethane recovery processes based on rich gas. Applied Thermal Engineering, 148, 105-119.

DOI:10.1016/j.applthermaleng.2018.11.046

20. Jin, C., \& Lim, Y. (2018). Economic evaluation of NGL recovery process schemes for lean feed compositions. Chemical Engineering Research and Design, 129, 297-305.

DOI:10.1016/j.cherd.2017.11.027

21. Jalali, A., Lotfi, M., Zilabi, S., \& Mohammadi, A. H. Recovery enhancement of liquid hydrocarbons in dew point control unit of natural gas processing plant. Separation Science and Technology 2019, 1-8. DOI:10.1080/01496395.2019.1591450
22. Lopez-Echeverry, J. S., Reif-Acherman, S., \& Araujo-Lopez, E. Peng-Robinson equation of state: 40 years through cubics. Fluid Phase Equilibria 2017, 447, 39-71.

DOI:10.1016/j.fluid.2017.05.007

23. Sodeifian, G., Ardestani, N. S., Sajadian, S. A., \& Panah, H. $\mathrm{S}$. Measurement, correlation and thermodynamic modeling of the solubility of Ketotifen fumarate (KTF) in supercritical carbon dioxide: evaluation of PCP-SAFT equation of state. Fluid Phase Equilibria 2018, 458, 102-114.

DOI:10.1016/j.fluid.2017.11.016

24. Guo, G., Wang, F., Liu, G. Q., Luo, S. J., \& Guo, R. B. Calculation on the phase equilibrium and critical temperature of $\mathrm{CH}_{4} / \mathrm{CO}_{2}$. Process Safety and Environmental Protection 2018, 113, 369-377. DOI:10.1016/j.psep.2017.11.007

25. Sodeifian, G., Ardestani, N. S., \& Sajadian, S. A. Solubility measurement of a pigment (Phthalocyanine green) in supercritical carbon dioxide: Experimental correlations and thermodynamic modeling. Fluid Phase Equilibria 2019, 494, 61-73. DOI:10.1016/j.fluid.2019.04.024

26. Farzaneh-Gord, M., \& Rahbari, H. Developing novel correlations for calculating natural gas thermodynamic properties. Chemical and Process Engineering 2011, 32(4), 435-452. DOI:10.2478/v10176-011-0035-1

27. Konukman, A. E. S., \& Akman, U. Flexibility and operability analysis of a HEN-integrated natural gas expander plant. Chemical Engineering Science 2005, 60(24), 7057-7074. DOI:10.1016/j.ces.2005.05.070

28. Jalali, A., Lotfi, M., Zilabi, S., \& Mohammadi, A. H. Recovery enhancement of liquid hydrocarbons in dew point control unit of natural gas processing plant. Separation Science and Technology 2019, 1-8. DOI:10.1080/01496395.2019.1591450

\section{Povzetek}

Naravni plin predstavlja splošno uporabno plinsko mešanico. Poznavanje njegovih termodinamskih lastnosti je zato ključnega pomena za načrtovanje procesa in opreme. $\mathrm{V}$ tem delu smo določali energijo, ki jo lahko pridobimo iz naravnega plina z uporabo ekspanzijske turbine. Na osnovi energijske in eksergijske analize smo s pomočjo računalniškega programa MATLAB preučili naravne pline različnih sestav iz šestih plinskih polj v Egiptu. Izvedli smo numerične simulacije siromašnih in bogatih plinskih mešanic in preučili vpliv naraščajoče vsebnosti $\mathrm{C} 1$ in $\mathrm{C} 5$ na energijski izkoristek ter rezultate validirali. Rezultati so pokazali podobne trende in dobro ujemanje. Ugotovili smo, da eksergijska učinkovitost pada $\mathrm{z}$ naraščanjem koncentracije metana v plinski mešanici. Rezultati so tudi pokazali, da so termodinamske lastnosti plinske mešanice odvisne od relativnega deleža težjih komponent.

Except when otherwise noted, articles in this journal are published under the terms and conditions of the Creative Commons Attribution 4.0 International License 